\title{
Depathologizing Sexual Orientation and Transgender Identities in Psychiatric Classifications
}

\author{
Депатологизация сексуальной ориентации и трансгендерной идентичности \\ в психиатрических классификациях \\ doi:10.17816/CP61
}

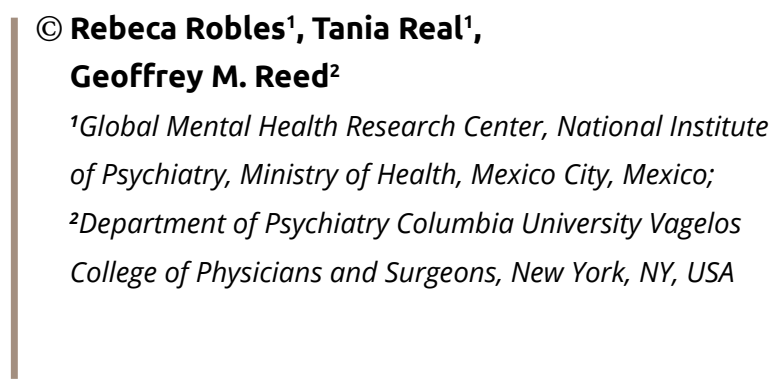

\author{
(C) Ребека Роблес ${ }^{1}$, Таня Рил'1, \\ Джеффри М. Рид² \\ ${ }^{1}$ Центр исследований глобального психического \\ здоровья, Национальный институт психиатрии, \\ Министерство здравоохранения, Мехико, Мексика; \\ ${ }^{2}$ Кафедра психиатрии, Высшая медицинская школа \\ Валегоса, Колумбийский университет, Нью-Йорк, \\ uтат Нью-Йорк, США
}

\begin{abstract}
Introduction. This article presents the history and rationales of conceptualization and classification of homosexuality and transgender identity in both ICD and DSM. We review the efforts that have been made (and those that remain pending) to improve psychiatric classifications with new scientific knowledge, changing social attitudes and human rights standards.
\end{abstract}

Method. We conducted a literature search of the classification of homosexuality and transgender identity as mental disorders.

Result. We provide a historical description of these concepts in ICD and DSM, including fundamental points of disagreement as well as arguments that have been effective in achieving changes in both classifications.

Conclusions. Fundamental changes have been made in the International Classification of Diseases Eleventh Revision (ICD-11) in terms of the classification of sexual orientation and gender identity based on scientific evidence and the ICD's public health objectives. These changes might support the provision of accessible and high-quality healthcare services, and are responsive to the needs, experience and human rights of the populations involved.

\section{АННОТАЦИЯ}

Введение. Данная статья представляет историю развития взглядов в отношении концептуализации и квалификации гомосексуальности и трансгендерной идентичности, а также обоснование изменений, которые произошли как в Международной классификации болезней (МКБ), так и в Диагностическом и статистическом руководстве по психическим расстройствам (DSM). С учетом новых научных знаний, смены социальных установок и стандартов в области прав человека проанализированы усилия, которые были предприняты (и те, что еще предстоит предпринять) для совершенствования классификаций психических расстройств. 
Материал и методы. Проведен поиск литературы по теме классификации гомосексуальности и трансгендерной идентичности как психических расстройств.

Результаты. Дано описание этих понятий в различных версиях МКБ и DSM, включая основные расхождения, равно как и аргументы для изменений, произошедших в обеих классификационных системах.

Выводы. В МКБ-11 были внесены фундаментальные с точки зрения классификации сексуальной ориентации и гендерной идентичности изменения, в основу которых легли научные доказательные данные, а также цели МКБ в отношении общественного здравоохранения. Эти изменения могут способствовать обеспечению доступной высококвалифицированной помощи для определенных групп населения, а также отвечают их нуждам, собственному опыту и требованиям защиты прав человека.

Keywords: depathologization; homosexuality; transgender identity; ICD-11; DSM-5

Ключевые слова: депатологизация; гомосексуальность; трансгендерные формы идентичности; МКБ-11; DSM-5

\section{INTRODUCTION}

According to recent international surveys of psychiatrists from 44 countries ${ }^{1}$ and psychologists from 23 nations, ${ }^{2}$ the $10^{\text {th }}$ version of the International Classification of Diseases and Related Health Problems (ICD-10) ${ }^{3}$ is the classification system that both groups of clinicians use most in their everyday clinical work $(70.1 \%$ of psychiatrists, and $51 \%$ of psychologists), followed by the American Psychiatric Association's Diagnostic and Statistical Manual of Mental Disorders $(\mathrm{DSM})^{4}(23 \%$ of psychiatrists, and $43.8 \%$ of psychologists).

Although there are several benefits associated with the use of these classifications, their critical examination is important to reduce psychiatry's vulnerability to political ideologies, economic goals, stigmatizing attitudes and other forms of abuse. ${ }^{5}$ From this perspective, throughout the history of these classification systems, one of the fundamental points of disagreement has been the conceptualization and classification of conditions related to homosexuality and transgender identity as mental disorders. The classification of homosexuality and transgender identity as mental disorders has been used, for example, to justify the implementation of "corrective" therapies, ${ }^{6,7}$ a practice that is now prohibited in a growing number of countries where LGBTaffirmative psychological services ${ }^{8}$ are now considered the standard of care.

\section{A BRIEF HISTORY OF THE CLASSIFICATION OF HOMOSEXUALITY}

The ICD and DSM's first classifications of homosexuality conceptualized it as a sexual deviation. ICD- 6 was the first version of the ICD that included a classification of morbidity and the first version to incorporate a classification of mental disorders. Prior to ICD-6 and founding of WHO, ICD was exclusively a classification of mortality, the first version being called The International List of Causes of Death. From ICD-6 (approved in 1948), through ICD-7 (approved in 1955), ICD-8 (approved in 1965) and ICD-9 (approved in 1975), homosexuality was included in Chapter V on mental disorders, and also as part of a general category for "Sexual Deviation". Table 1 shows the specific blocks, groups and categories (and corresponding codes) used to classify, in a single group, a set of very different conditions currently understood as conditions related to sexual orientation (e.g., homosexuality), gender identity or sexual preferences.

According to Mendelson, ${ }^{9}$ the first ICD definition of sexual deviation was included in the Glossary of Mental Disorders and Guide to their Classification (issued in 1974 for use in conjunction with the eighth revision of the ICD) and conceptualized homosexuality, as well as transvestitism, fetishism, exhibitionism, sadomasochism and bestiality, as manifestations of the presence of a persistent abnormality of the sexual impulse. In the ICD-9 expanded glossary, sexual deviations were described as abnormal sexual inclinations or behaviours directed primarily towards people not of the opposite sex, or towards sexual acts not normally associated with coitus, or towards coitus performed under abnormal circumstances.

Regarding the APA's classification, from its first edition (DSM-I, published in 1952) until the sixth printing of its second edition (DSM-II, published in 1968), homosexuality 


\begin{tabular}{|c|c|c|c|}
\hline & ICD-6 and ICD-7 & ICD-8 & ICD-9 \\
\hline Chapter name & $\begin{array}{l}\text { Chapter V. Mental, } \\
\text { psychoneurotic and personality } \\
\text { disorders }\end{array}$ & Chapter V. Mental disorders & Chapter V. Mental disorders \\
\hline Block name and codes & $\begin{array}{l}\text { Disorders of character, } \\
\text { behaviour and intelligence } \\
\text { (codes 320-326) }\end{array}$ & $\begin{array}{l}\text { Neurosis, personality disorders } \\
\text { and other non-psychotic mental } \\
\text { disorders (codes 300-309) }\end{array}$ & $\begin{array}{l}\text { Neurotic disorders, personality } \\
\text { disorders and other non- } \\
\text { psychotic mental disorders } \\
\text { (codes 300-316) }\end{array}$ \\
\hline Group name and code & $\begin{array}{l}\text { Pathologic personality } \\
\text { (code } 320 \text { ) }\end{array}$ & $\begin{array}{l}\text { Sexual deviation } \\
\text { (code 302) }\end{array}$ & $\begin{array}{l}\text { Sexual disorders and deviation } \\
\text { (code 302) }\end{array}$ \\
\hline $\begin{array}{l}\text { Category names, codes and } \\
\text { conditions included }\end{array}$ & $\begin{array}{l}320.6 \text { Sexual deviation } \\
\text { Includes: exhibitionism, } \\
\text { fetishism, homosexuality, } \\
\text { pathologic sexuality, sadism, } \\
\text { sexual deviation }\end{array}$ & $\begin{array}{l}\text { 302.0 Homosexuality Includes: } \\
\text { lesbianism, sodomy } \\
\text { 302.1 Fetishism } \\
\text { 302.2 Paedophilia } \\
\text { 302.3 Transvestitism } \\
\text { 302.4 Exhibitionism } \\
\text { 302.8 Other sexual deviation } \\
\text { Includes: erotomania, } \\
\text { masochism, narcissism, } \\
\text { necrophilia, nymphomania, } \\
\text { sadism, voyeurism } \\
\text { 302.9 Unspecified } \\
\text { sexual deviation } \\
\text { Includes: pathological sexuality } \\
\text { NOS, sexual deviation NOS }\end{array}$ & $\begin{array}{l}\text { 302.0 Homosexuality Includes: } \\
\text { lesbianism } \\
\text { 302.1 Bestiality } \\
\text { 302.2 Paedophilia } \\
\text { 302.3 Transvestism } \\
\text { 302.4 Exhibitionism } \\
\text { 302.5 Transsexualism } \\
\text { 302.6 Disorders of } \\
\text { psychosexual identity } \\
\text { Includes: gender-role disorder } \\
\text { 302.7 Frigidity and impotence } \\
\text { Includes: psychogenic } \\
\text { dyspareunia } \\
\text { 302.8 Other sexual } \\
\text { deviation or disorder } \\
\text { Includes: fetishism, masochism, } \\
\text { sadism } \\
\text { 302.9 Unspecified sexual } \\
\text { deviation or disorder }\end{array}$ \\
\hline
\end{tabular}

was specifically included in the rubric of "Sexual Deviation", together with other conditions related to sexuality such as fetishism, paedophilia, transvestitism and sadism. In DSM-I, sexual deviations were categorized as "Sociopathic Personality Disturbances". In DSM-II, these conditions were placed in major subdivision $\mathrm{V}$, covering "Personality Disorders and Certain Other NonPsychotic Mental Disorders", with "homosexuality" as the category to be used "for individuals whose sexual interests are directed primarily toward people of the same sex..."10

The underlying assumption was that normal sexual orientation serves approved social and biological purposes, which runs counter to the current international acceptance of sexual rights (specifically the right to decide whether or not to reproduce). ${ }^{\mathbf{1 1}, 12}$ Radical changes to the conceptualization and classification of sexual conditions in general, particularly those related to sexual orientation and gender identity, required a major overhaul to bring them into line with the scientific literature.

The second era of homosexuality classification: Removing or replacing stigma?

An ambivalent attitude regarding the declassification of homosexuality was observed in the WHO'S ICD-10 (published in 1992). Although it was noted that "Sexual orientation alone is not to be regarded as a disorder", 3 
at least three ICD-10 codes (included in the "Psychological and Behavioural Disorders Associated with Sexual Development and Orientation" block, under the heading of "Disorders of Adult Personality and Behaviour"), specifically F66.0 ("Sexual Maturation Disorder"), F66.1 ("Ego-dystonic Sexual Orientation") and F66.2 ("Sexual Relationship Disorder"), could explicitly be applied based on a homosexual, heterosexual or bisexual orientation.

Sexual maturation disorder was defined as a mental disorder applied to an individual suffering from "uncertainty about his or her gender identity or sexual orientation, which causes anxiety or depression. Most commonly this occurs in adolescents who are not certain whether they are homosexual, heterosexual, or bisexual in orientation or in individuals who after a period of apparently stable sexual orientation, often within a long-standing relationship, find that their sexual orientation is changing." ${ }^{3}$

Ego-dystonic sexual orientation referred to an individual whose "gender identity or sexual preference is not in doubt, but the individual wishes it were different because of associated psychological and behavioural disorders and may seek treatment in order to change it. ". "Sexual Relationship Disorder" is a category for those whose "gender identity or sexual preference abnormality is responsible for difficulties in forming or maintaining a relationship with a sexual partner". ${ }^{3}$

Even though heterosexuality is also listed as a variation of sexual orientation that could be subcoded in any of these categories, heterosexual people were not the intended recipients of these diagnoses..$^{13}$ Clearly, those who exhibit a same-sex sexual orientation may also experience related distress. However, there is no evidence that same-sex sexual orientation itself is the cause of distress (i.e., a sexual maturation disorder or "ego-dystonic" homosexuality); rather, it seems that distress is a consequence of the social rejection and discrimination caused by stigma associated with their sexual orientation, ${ }^{14}$ which unfortunately continues to be very frequent. ${ }^{15}$ Moreover, given that ICD-10 does not include specific categories for relationship disorders due to other potential contributory factors, classification of the co-occurrence of relationship problems with a specific sexual orientation (or gender identity) is difficult to justify. ${ }^{16}$

Similarly, although homosexuality was removed from DSM-II in 1973, a category called "Sexual Orientation Disturbance" was included in the subsequent DSM-II reprints for those "disturbed by it, in conflict with it, or wishing to change their homosexual orientation". The main argument for its inclusion was that the presence of such subjective distress justified a diagnosis of a mental disorder.

Although scientific evidence available at the time challenged the assumption that homosexuality was a pathological condition per se, , $^{17-20}$ this special category remained in DSM-III (published in 1980) under a different name: "Ego-dystonic Homosexuality". The rationale for its inclusion was changed by adding "inherent disadvantage" as a second element of the definition of a mental disorder. ${ }^{21}$

Moreover, although the term Ego-dystonic Homosexuality no longer appeared in DSM-III-R (published in 1987), DSM-IV (published in 1994) or DSM-IV-TR (published in 2000), the category of "Sexual Disorders Not Otherwise Specified" opened the door to classify "persistent and marked distress about one's sexual orientation".

Table 2 summarizes the major subdivisions, groups and category names in the DSM's second stage of classification of homosexuality. The example provided for "Sexual Disorders Not Otherwise Specified" to classify the equivalent of ego-dystonic homosexuality is highlighted in bold.

The same criticisms used for the term "ego-dystonic homosexuality" could be applied to "sexual disorder not otherwise specified". If there are no categories of mental disorders for short people who are unhappy with their height, eye colour or complexion, then why should there be one for distress related to sexual orientation?22

As one would imagine, there were several mental health specialists who viewed retention of the ability to assign a mental disorder diagnosis on the basis of sexual orientation as representative of the traditional "homophobic bias" in the nomenclature, while other psychiatrists and psychoanalysts opposed removal of the original category of homosexuality, arguing that this occurred in response to an "indefensible response to gay pressure". ${ }^{21}$

\section{Complete declassification of homosexuality}

as a mental disorder in the DSM and ICD

Finally, ICD-11 and DSM-5, the current versions of the WHO and APA classifications, do not include a single category that could be applied to people based on their sexual orientation. ${ }^{23}$ 
Table 2. DSM-II (from 1974 onwards) to DSM-IV-TR: Categories related to homosexuality

\begin{tabular}{|c|c|c|c|c|}
\hline & $\begin{array}{l}\text { DSM-II ( } 7^{\text {th }} \text { and } \\
\text { subsequent } \\
\text { reprints) }\end{array}$ & DSM-III & DSM-III-R & DSM-IV and DSM-IV-TR \\
\hline $\begin{array}{l}\text { Major } \\
\text { subdivision }\end{array}$ & $\begin{array}{l}\text { Personality disorders } \\
\text { and certain other } \\
\text { non-psychotic } \\
\text { mental disorders }\end{array}$ & Psychosexual disorders & Sexual disorders & $\begin{array}{l}\text { Sexual and gender identity } \\
\text { disorders }\end{array}$ \\
\hline Group name & Sexual deviation & Other psychosexual disorders & Other sexual disorders & Other sexual disorders \\
\hline $\begin{array}{l}\text { Category } \\
\text { names and } \\
\text { criteria/ } \\
\text { examples }\end{array}$ & $\begin{array}{l}\text { Sexual orientation } \\
\text { disturbance } \\
\text { [homosexuality] }\end{array}$ & $\begin{array}{l}\text { Ego-dystonic homosexuality } \\
\text { Criteria: } \\
\text { A) The individual complains } \\
\text { that heterosexual arousalis } \\
\text { persistently absent or weak } \\
\text { and significantly interferes } \\
\text { with initiating or maintaining } \\
\text { wanted heterosexual } \\
\text { relationships; } \\
\text { B) There is a sustained } \\
\text { pattern of homosexual } \\
\text { arousal that the individual } \\
\text { explicitly states has been } \\
\text { unwanted and constitutes a } \\
\text { persistent source of distress. }\end{array}$ & \multicolumn{2}{|c|}{$\begin{array}{l}\text { Sexual disorder not otherwise specified } \\
\text { Examples: } \\
\text { (1) Marked feelings of inadequacy concerning body habitus, } \\
\text { size and shape of sex organs, sexual performance or other } \\
\text { traits related to self-imposed standards of masculinity or } \\
\text { femininity; } \\
\text { (2) Distress about a pattern of repeated sexual conquests or } \\
\text { other forms of non-paraphilic sexual addiction, involving a } \\
\text { succession of people who exist only as things to be used; } \\
\text { (3) Persistent and marked distress about one's sexual } \\
\text { orientation. }\end{array}$} \\
\hline
\end{tabular}

The ICD-11 Working Group on the Classification of Sexual Disorders and Sexual Health clarified that declassification of the ICD-10 "Psychological and Behavioural Disorders Associated with Sexual Development and Orientation" categories was based on their lack of usefulness for public health surveillance and clinical purposes, and their negative consequences, including mistakes or delays in accurate diagnosis and treatment, and ineffective and unethical "corrective" therapies. ${ }^{16}$

\section{PSYCHIATRIC CLASSIFICATION OF GENDER IDENTITY}

The history of psychopathological classification of transgender identity in the DSM and ICD has a number of parallels with the one presented above for sexual orientation, mainly in connection with activism and arguments used to call for the removal of transgender diagnoses from mental disorder classifications, ${ }^{24}$ although different decisions were taken by the developers of the two classification systems. Given the importance of reducing the stigmatization of this population and ensuring quality health and mental health services if required, ${ }^{25}$ in ICD-11, transgender conditions were moved from the chapter on mental and behavioural disorders to a new chapter on "Conditions Related to Sexual Health", while DSM-5 changed the name of the conditions, eliminating the word "disorder" but retaining them as mental disorders.

\section{History of the classification of transgender conditions in the DSM and ICD}

According to Zucker and Spitzer, ${ }^{26}$ since the middle of the $20^{\text {th }}$ century - particularly the $1960 \mathrm{~s}$ - awareness of transgender phenomena seems to have increased considerably among health and mental health professionals. During this period, many of them consideredtransgender identity to be a psychopathological expression of human behaviour ${ }^{27}$ or a biological disorder. ${ }^{28}$

However, unlike homosexuality, transgender phenomena were not included in the first editions of either ICD or DSM. It was not until the end of the last century, when ICD-9 (1978) and DSM-III (1980) were published, 


\begin{tabular}{|l|l|l|l|}
\hline & DSM-III & DSM-III-R & DSM-IV and DSM-IV-TR \\
\hline Major subdivision & $\begin{array}{l}\text { Psychosexual } \\
\text { disorders }\end{array}$ & $\begin{array}{l}\text { Disorders usually first evident } \\
\text { in infancy, childhood or } \\
\text { adolescence }\end{array}$ & Sexual and gender identity disorders \\
\hline Category names & $\begin{array}{l}\text { Gender identity } \\
\text { disorder in childhood } \\
\text { Transsexualism } \\
\text { (adolescents and } \\
\text { adults) }\end{array}$ & $\begin{array}{l}\text { Gender identity disorder } \\
\text { in childhood } \\
\text { Transsexualism (adolescents } \\
\text { and adults) } \\
\text { Gender identity disorder } \\
\text { in adolescence and adulthood, } \\
\text { non-transsexual type }\end{array}$ & $\begin{array}{l}\text { Gender identity disorder (with one set } \\
\text { of criteria for children and another for } \\
\text { adolescents and adults) }\end{array}$ \\
\hline
\end{tabular}

that psychiatric diagnoses related to transgender identity appeared for the first time. Table 3 shows the major subdivisions and categories used to classify transgender conditions through DSM-III to DSM-IV-TR (see Table 1 for ICD-8 and ICD-9 categories, highlighted in bold).

In the ICD-10 chapter on Mental and Behavioural Disorders ${ }^{3}$ (specifically section F64 on gender identity disorders), the diagnoses for transgender identity were exactly the same as those in DSM-III (gender identity disorder of childhood and transsexualism for adolescents and adults). Other ICD-10 categories for paraphilias that could be related to transgender phenomena are "Dual Role Transvestism" and "Fetishistic Transvestism".

Interestingly, Stoller (and other psychiatrists and psychoanalysts who supported the APA's decision to remove homosexuality from DSM-II) recommended the inclusion of categories related to transgender identity in DSM-III. According to other contemporary experts in this area, ${ }^{24}$ this suggestion was based on a psychopathological conceptualization of transgender identity as a separation-individuation problem. ${ }^{29}$

Current categories related to gender identity: Differences between ICD-11and DSM-5 ICD-11 and DSM-5 working groups wrestled with two main challenges: how to reduce stigma (which underlies the international call for removal of transgender diagnoses from mental disorder classifications by a number of civil societies, professional organizations and the European Parliament) ${ }^{23,30,31}$ while maintaining access to care(when this requires the existence of a diagnosis in order to obtain needed medical treatment covered by third party payers). ${ }^{32}$

In both classification systems, the name of the categories related to transgender conditions was changed in order to reduce stigma, eliminating the word "disorder" and opting for labels that better express the subjective experience of cross-gender identity. ${ }^{25}$ In ICD-11, they are: "Gender Incongruence in Childhood" and "Gender Incongruence in Adolescence and Adulthood", whereas in DSM-5,these are "Gender Dysphoria in Children" and "Gender Dysphoria in Adolescents or Adults".

Nevertheless, the need for diagnostic categories that ensure healthcare reimbursement of gender-affirming treatments for transgender people was resolved in different ways by ICD-11 and DSM-5. In the APA classification, consisting exclusively of mental disorders, transgender categories are retained as mental disorders, whereas in the WHO classification system (which comprises and could introduce different chapters for health-related conditions), these categories were moved from the chapter on mental, behavioural and neurodevelopmental disorders to a new chapter on conditions related to sexual health. Consistent with the conceptualization of transgender identity as not being a mental disorder, in ICD-11, distress and functional impairment are identified as commonly occurring in response to experiences of stigmatization and victimization, but they are not diagnostic requirements. In DSM-5, distress or impairment-generally a requirement 
for the diagnosis of a mental disorder-is also required for a diagnosis of gender dysphoria.

Moreover, a redefinition of gender incongruence was introduced in ICD-11 in order to describe the condition more thoughtfully in a non-binary way as "marked and persistent incongruence between an individual's experienced gender and the assigned sex" to live and be accepted as a member of the opposite sex, usually accompanied by a sense of discomfort with, or inappropriateness of, one's anatomic sex and a wish to have hormonal treatment and surgery to make one's body as congruent as possible with the preferred sex". ${ }^{3}$

Additionally, the ICD-11 diagnostic guidelines modified the time required to establish the diagnosis. In the case of the condition in adolescence and adulthood, this involved changing the time limit from "two years" to "several months" (to facilitate access to quality healthcare). The opposite was done for childhood diagnosis by increasing the time required for diagnosis to two years in order to avoid false positives based on gender-variant behaviours, common in early stages of life.

The main ICD-11 proposals were subjected to field testing in a variety of relevant healthcare settings in different WHO regions, including low-, middle- and high-income countries. Field testing of the transgender category for adolescents and adults focused mainly on assessing: 1) whether or not the transgender condition is a mental disorder (by determining whether distress and dysfunction are more related to social rejection than to gender incongruence); 2) whether the ICD-11 set of criteria are more clinically useful than the DSM-5 criteria (by evaluating whether sex-changing treatment with hormones and/or surgery is predicted by variables related to marked gender incongruence rather than experienced distress or impairment); and 3) the sensitivity and specificity of two sets of diagnostic criteria to establish the presence of gender incongruence (Gl), considering distress and/or impairment as diagnostic requirements (DSM-5) or not, in the case of ICD-11.

This was the scope of field testing of the ICD-11 changes in the condition for adolescence and adulthood, given the main arguments of those opposing its declassification as a mental disorder, as summarized by Drescher, CohenKettenis and Winter: "While reducing the stigmatization of mental disorders is important, the argument to remove a diagnostic category from the mental disorders section of the ICD simply because mental disorders are stigmatized is neither compelling nor persuasive." 25

Field studies confirmed the following: the distress and dysfunction of transgender people are related more to social rejection and violence than gender incongruence per se; the inclusion of distress and/or dysfunction as diagnostic requirements (as in DSM-5) does not help to identify transgender people seeking medical treatment or even to distinguish between transgender and non-transgender people; ${ }^{34,35}$ the diagnoses received in childhood are non-specific rather than formal gender identity diagnoses, and although such diagnoses are experienced as negative and are used to justify potentially harmful interventions, the ICD-11 category for the transgender condition in childhood is necessary and important and could have a range of personal, familial and social benefits. ${ }^{7}$

Finally, in May 2019, the World Health Assembly approved the new ICD-11, including changes to the name, and the conceptualization (diagnostic requirements) and location of transgender conditions in childhood, adolescence and adulthood.

\section{CONCLUSION}

Over the last half-century, social forces and scientific data have made it possible to view homosexuality and transgender identity as non-pathological variants of human experience. It is not surprising that, for example, in surveys of psychiatrists and psychologists prior to the development of ICD-11 (ICD-10 and DSM-IV were in use at the time of the surveys), the category most frequently recommended for deletion was "Gender Identity Disorder", usually because clinicians regarded it as being based on stigmatization of a way of being and behaving. ${ }^{34}$

Given that ICD is the most widely used classification system worldwide, changes in ICD-11 related to the classification of sexual orientation and gender identity have been particularly important. These changes reflect current scientific evidence and best practice; they support the provision of accessible and high-quality healthcare services; and they are responsive to the needs, experience and human rights of the populations involved. However, further efforts to eliminate stigma, discrimination and violence against sexual and gender minorities are still necessary. These should include health professionals and society as a whole but also new researchers in the 
field, in order to make further steps in healthcare more scientifically based and reasoned.

Authors contribution: Rebeca Robles: planning, searching, retrieval and selection of data, text preparation; Tania Real: searching and retrieval of data, text preparation, editing; Geoffrey M Reed: planning, methodology, editing.

Funding: The review was carried out without additional funding.

Conflict of interest: The authors declare no conflicts of interest.

\section{Correspondence to:}

\section{Rebeca Robles, PhD}

reberobles@hotmail.com

\section{For citation:}

Robles R, Real T, Reed GM. Depathologizing sexual orientation and transgender identities in psychiatric classifications. Consortium Psychiatricum. 2021;2(2): 45-53. doi:10.17816/CP61

\section{References}

1. Reed GM, Mendonca Correia J, Esparza P, et al. The WPAWHO Global Survey of Psychiatrists' Attitudes Towards Mental Disorders Classification. World Psychiatry. 2011;10(2):118-131. doi:10.1002/j.2051-5545.2011.tb00034.x

2. Evans SC, Reed GM, Roberts MC, et al. Psychologists' perspectives on the diagnostic classification of mental disorders: results from the WHO-IUPsyS Global Survey. Int J Psychol. 2013;48(3):177-193. doi:10.1080/00207594.2013.804189

3. World Health Organization. The ICD-10 Classification of Mental and Behavioral Disorders. Clinical Descriptions and Diagnostic Guidelines. World Health Organization; 1992.

4. American Psychiatric Association. Diagnostic and Statistical Manual of Mental Disorders. 4th ed. American Psychiatric Association; 1994.

5. Jablensky A, Kendel RE. Criteria for Assessing a Classification in Psychiatry. In: M. Maj, G. Wolfgan, J. J. López-Ibor, N. Sartorius. Psychiatric Diagnosis and Classification. John Wiley \& Sons, Ltd; 2002.

6. Carr S, Spandler H. Hidden from history? A brief modern history of the psychiatric "treatment" of lesbian and bisexual women in England. Lancet Psychiatry. 2019;6(4):289-290. doi:10.1016/S22150366(19)30059-8

7. Vargas-Huicochea I, Robles R, Real T, et al. A Qualitative Study of the Acceptability of the Proposed ICD-11 Gender Incongruence of Childhood Diagnosis Among Transgender Adults Who Were Labeled Due to Their Gender Identity Since Childhood. Arch Sex Behav. 2018;47(8):2363-2374. doi:10.1007/s10508-018-1241-4

8. Bidell MP. Mind our professional gaps: Competent lesbian, gay, bisexual, and transgender mental health services. Counselling Psychol Review, 2016;31(1):67-76.

9. Mendelson G. Homosexuality and psychiatric nosology. Aust N ZJ Psychiatry. 2003;37(6):678-683. doi:10.1080/j.14401614.2003.01273.x

10. American Psychiatric Association. Diagnostic and Statistical Manual of Mental Disorders. 2nd ed. American Psychiatric Association; 1986.

11. International Planned Parenthood Federation. Sexual rights: an IPPF declaration. IPPF; 2006.

12. World Association for Sexual Health. Declaration of sexual rights. Published September 3, 2014. Accessed April 7, 2021. http://www. worldsexology.org/resources/declaration-of-sexual-rights/

13. Cochran SD, Drescher J, Kismodi E, et al. Proposed declassification of disease categories related to sexual orientation in the International Statistical Classification of Diseases and Related Health Problems (ICD-11). Bull World Health Organ. 2014;92(9):672679. doi:10.2471/BLT.14.135541

14. Mays VM, Cochran SD. Mental health correlates of perceived discrimination among lesbian, gay, and bisexual adults in the United States. Am J Public Health. 2001;91(11):1869-1876. doi:10.2105/ajph.91.11.1869

15. United Nations High Commissioner for Human Rights. Discriminatory laws and practices and acts of violence against individuals based on their sexual orientation and gender identity. United Nations; 2011.

16. Cochran SD, Drescher J, Kismodi E, et al. Proposed declassification of disease categories related to sexual orientation in the International Statistical Classification of Diseases and Related Health Problems (ICD-11). Bull World Health Organ. 2014;92(9):672679. doi:10.2471/BLT.14.135541

17. Bayer R. Politics, science, and the problem of psychiatric nomenclature: A case study of the American Psychiatric Association referendum on homosexuality. In: Engelhardt Jr. $\mathrm{H}$, Caplan A. Scientific Controversies: Case Studies in the Resolution and Closure of Disputes in Science and Technology. Cambridge University Press; 1987. doi:10.1017/CBO9780511628719.018

18. Hooker E. The adjustment of the male overt homosexual.J Proj Tech. 1957;21(1):18-31. doi:10.1080/08853126.1957.10380742

19. Hooker E. Reflections of a 40-year exploration. A scientific view on homosexuality. Am Psychol. 1993;48(4):450-453. doi:10.1037//0003-066x.48.4.450

20. Stoller RJ. Criteria for Psychiatric Diagnosis. In: Stoller RJ, Marmor J, Bieber I, et al. A symposium: Should homosexuality be in the APA nomenclature? Am J Psychiatry. 1973;130(11):1207-1216.

21. Bayer R, Spitzer RL. Edited correspondence on the status of homosexuality in DSM-III. J Hist Behav Sci. 1982;18(1):3252. doi:10.1002/1520-6696(198201)18:1<32::aidjhbs2300180105>3.0.co;2-0

22. Mass L. The birds, the bees and John Money: A conversation with sexologist John Money. In: Mass L. Homosexuality and sexuality: Dialogues of the sexual revolution. Harrington Park Press; 1990.

23. Reed GM, Drescher J, Krueger RB, et al. Disorders related to sexuality and gender identity in the ICD-11: revising the ICD-10 classification based on current scientific evidence, best clinical practices, and human rights considerations. World Psychiatry. 2016;15(3):205-221. doi:10.1002/wps.20354

24. Drescher J. Queer diagnoses: parallels and contrasts in the history of homosexuality, gender variance, and the diagnostic and statistical manual. Arch Sex Behav. 2010;39(2):427-460. doi:10.1007/s10508-009-9531-5 
25. Drescher J, Cohen-Kettenis P, Winter S. Minding the body: situating gender identity diagnoses in the ICD-11. Int Rev Psychiatry. 2012;24(6):568-577. doi:10.3109/09540261.2012.741575

26. Zucker KJ, Spitzer RL. Was the Gender Identity Disorder of Childhood Diagnosis Introduced into DSM-III as a Backdoor Maneuver to Replace Homosexuality? A Historical Note. Journal of Sex \& Marital Therapy. 2005;31(1):31-42. doi:10.1080/00926230590475251

27. Krafft-Ebing R. Psychopathia sexualis: A medico-forensic study. Putnam; 1965.

28. Benjamin $\mathrm{H}$. The transsexual phenomenon: A scientific report on transsexualism and sex conversion in the human male and female. Julian Press; 1966.

29. Stoller RJ. Presentations of gender. Yale University Press; 1985.

30. Coordination Team of STP, International Campaign Stop Trans Pathologization. Recent Developments related to the DSM and ICD Revision Processes. STP, International Campaign Stop Trans Pathologization. Published June, 2016. Accessed April 7, 2021. http://www.stp2012.info/STP_Communique_DSM_ICD.pdf

31. Knudson G, De Cuypere G, Bockting W. Recommendations for Revision of the DSM Diagnoses of Gender Identity Disorders:
Consensus Statement of the World Professional Association for Transgender Health. Int J of Transgend Health. 2010;12(2):115-118. doi:10.1080/15532739.2010.509215

32. Drescher J. Controversies in Gender Diagnoses. LGBT Health. 2014;1(1):10-14. doi:10.1089/lgbt.2013.1500

33. World Health Organization. International Classification of Diseases 11th Revision, 2019. The global standard for diagnostic health information. Accessed April 7, 2021. https://icd.who.int/en/

34. Robles R, Fresan A, Vega-Ramirez $\mathrm{H}$, et al. Removing transgender identity from the classification of mental disorders: a Mexican field study for ICD-11. Lancet Psychiatry. 2016;3(9):850-859. doi:10.1016/S2215-0366(16)30165-1

35. Robles R, Sharan P, Purnima S, et al. Sources of distress and dysfunction among transgender people: An international research programme for ICD-11. In: Robles R. Proceedings of the first symposium “Diagnosis, health policy, human rights, and forensic considerations: Transgender people, sexual minorities, and sexual disorders in Latin America"; 2018 Septenber 27-30; Mexico City. World Congress of Psychiatry; 2018. 